\title{
PSYCHE.
}

ORGAN OF THE CAMBRIDGE ENTOMOLOGICAL CLUB EDITED BY B. PICKMAN MANN.

Vol. I.] Cambridge, Mass., July, 1876. [No. 27.

\section{Synoptical Tables for determining N. A. Insects.} Orthoptera - U. S. Forficulariae. ${ }^{1}$

1 (6) Sixth antennal joint much shorter than the first.

2 (5) First antennal joint as long as the fourth to sixth joints inclusive. 3 (4) Furnished with both tegmina and wings . 1. Labidura riparia.

4 (3) Possessed of neither tegmina nor wings. 2. Anisolabis maritima.

5 (2) First antennal joint no longer than the fourth and fifth joints together. . . . . . . . 3. Spongophora brunneipennis.

6 (1) Sixth antennal joint as long, or very nearly as long as the first.

7 (18) Sixth antennal joint cylindrical, many times longer than broad; second tarsal joint produced beneath the third.

8 (9) Wings wanting, or shorter than the tegmina.

4. Forficula aculeata.

9 (8) Wings protruding beyond the tips of the tegmina.

10 (13) Middle legs very much nearer the fore than the hind legs.

11 (12) Male forceps attingent at extreme base.

5. Forficula auricularia.

12 (11) Male forceps widely separate at extreme base.

6. Forficula taeniata.

13 (10) Middle legs only a little nearer the fore than the hind legs.

14 (15) Inner edge of male forceps with a post-median tooth.

7. Forficula exilis.

15 (14) Inner edge of male forceps with no distinct post-median tooth.

16 (17) Inner edge of male forceps sharply and profusely denticulate . . . . . 8. Forficula californica.

17 (16) Inner edge of male forceps with a single sharp basal tooth . . . . . . . . 9. Forficula pulchella.

18 (7) Sixth antennal joint plainly obconic; second tarsal joint simple, compressed.

${ }^{1}$ A synopsis of all the N. A. species has just appeared in the Bull. U. S. Geol. and Geogr. Serv. Terr., vol. ii. [See Bibl. Rec., No. 571.] 
19 (20) Wings wanting, or shorter than the tegmina.

10. Labia Burgessi.

20 (19) Wings protruding beyond the tips of the tegmina.

21 (22) Forceps of female scarcely flattened beneath, with rounded lateral edges . . . . . . . 11. Labia minor.

22 (21) Forceps of female flattened beneath, with sharp lateral edges.

23 (24) Exposed part of wings with a distinct yellow spot.

12. Labia guttata.

24 (23) Exposed part of wings unicolorous.

13. Labia melancholica.

This table does not include Forficula Percheroni Guér., described by me fourteen years ago (as Spongophora bipunctata) from a broken specimen in the Harris collection, supposed to have come from Massachusetts. If it did, it was probably introduced accidentally, as it has not since been captured in the United States. Nos. 1, 2,5 and 11 are also found in the Old World.

A general catalogue of Forficulariae, by the writer, will be found in Vol. xviii of the Proceedings of the Boston Society of Natural History, where will be found references to the best deseriptions of the species. Original descriptions of most of the N. American species will be found in the Orthoptères of Serville (Suites à Buffon), the Handbuch der Entomologie (Vol. 2) of Burmeister, Dohrn's Dermapteren von Mexico (Stett: Entom. Zeit., Jahrg. 23), the Monographie der Dermapteren of the same author (ibid., Jahrg. 24-26), and in my Century of Orthoptera and other papers (Proc. Bost. Soc. Nat. Hist., Vol. 18). Other descriptions will be found in Palisot de Beauvois (Ins. Afr. et Amer.), Guérin (Sagra's Cuba) and the general writings of Linné and Fabricius.

The latest views on the classification of Forficulariae will be found in Dohrn's Monograph, above eited. The anatomy of the group has been studied by Posselt (Inaug. Dissert., 1800), Dufour (Ann. Sc. Nat., 1828; Rech. anat. et phys. sur les Orth., etc., 1841), Lacaze-Duthiers (Ann. Sc. Nat., 1852), Meinert (Naturh. Tidsskr. [3] 5), and in a more general way by several other authors, Serres, Newport, etc. On the structure of the wings and their manner of folding, see a paper shortly to appear in the American Naturalist. Fossil species have been described by Herr, Massalongo, Weyenbergh and Scudder.

Samuel H. Scudder.

Remarkable Tenacity of Life. Yesterday afternoon, between two and three p.m., I collected a number of Coleoptera, among which were Lophoglossus strenuus, Helops micans, Helops aereus, several Pterostichi and Platyni. I arrived at home a little after five p.m., and, after the perusal of some letters, went to pick out the specimens. All except L. strenuus and $H$. micans were pasted on cards. About fifteen minutes afterwards the six 
specimens of Helops aereus began to move about on the cards, trying to free their legs from the nearly dry shellac. Some chloroform poured into the box helped the poor creatures into a better existence. This tenacity of life is remarkable, as none of the other beetles, after having been in the alcohol for some three hours, were found to be alive. There must be a sort of respiratory receptacle under the elytra, analogous to that of certain water-beetles.

C. F. Gissler, Brooklyn, N. Y., May 7th, 1876.

\section{BIBLIOGRAPHICAL RECORD.}

Authors and Societies are requested to forward their works to the Editor at the earliest date possible. We ask our readers to inform us of the publication especially of those works which are not generally consulted by entomologists.

B. Pickman Mann.

(Continued from page 176.)

Nos. 533 and 534 are from the Can. Entom., vol. vii (cont.).

* 533. F. B. Caulfield. List of Sphingidæ and Zygænidæ occurring on the Island of Montreal, P. Q. p. 241-242.

Enumerates 28 species, with notes on abundance and seasons.

* 534. C. W. Pearson. Excursion of the Montreal Branch to Chateauguay Basin, on Dominion Day. p. 242-244.

Itinerary; list of 32 Lepidoptera taken June 30 and July $1,1875$.

* 535. The Fourth Annual Report of the Secretary of the State Pomological Society of Michigan, 1874. By Authority. Lansing, 1875, contains the following, and Nos. 536 to 538 .

a. Need of greater attention to economic entomology (by G. Parmelee), 11-12. b. Aegeria exitiosa, pp. 31, 560 ; Conotrachelus nenuphar, pp. 3536, 38-39, 237-240, 482-483, 491; Carpocapsa pomonella, pp. 69-70, 104, 106, 484, 533, 535, 547; Doryphora 10-lineata, pp. 71, 74; Phylloxera vastatrix, p. 72; Ellopia ribearia, p. 74; Nematus ventricosus, pp. 379-380, $559-560$; orchard enemies, pp. 74, 486, 489, 490-491, 559-560; means against these and other injurious insects.

[In correction of Rec., No. 108 a, Prof. Cook writes: "I am not State Entomologist, but am Prof. of Entomology here [Lansing] and an officer of the Pom. Society, and so do what work my time as teacher will permit."]

* 536. A. J. Cook. The Codling Moth. p. 152-160.

Habits, seasons, description and enemies of Carpocapsa pomonella; means against it.

* 537. A. J. Cook. Economic Entomology. Its History, Progress, and needs in the United States. p. 176-183.

Notice of the labors of Harris, Fitch, Walsh, Riley, LeBaron, Packard, 

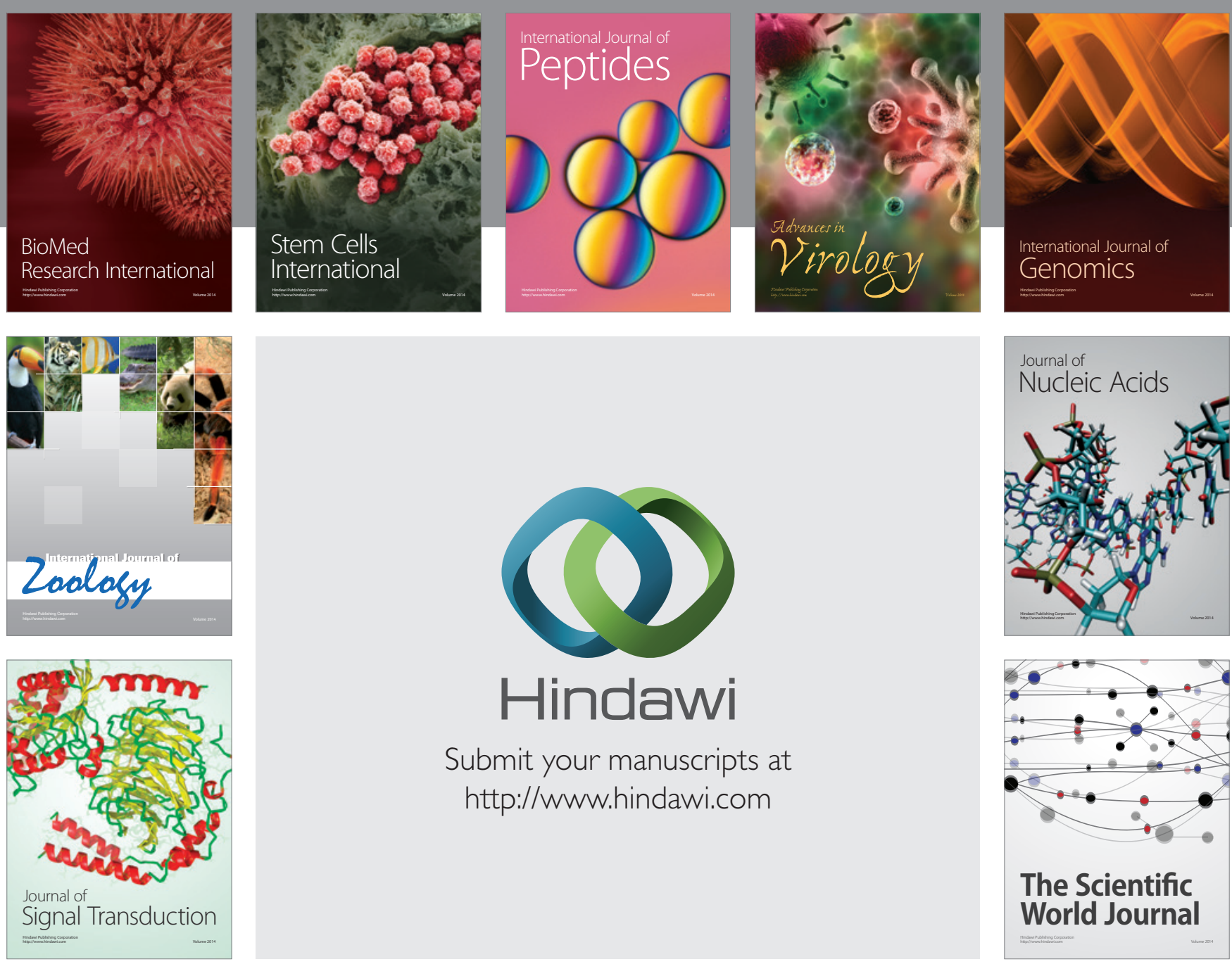

Submit your manuscripts at

http://www.hindawi.com
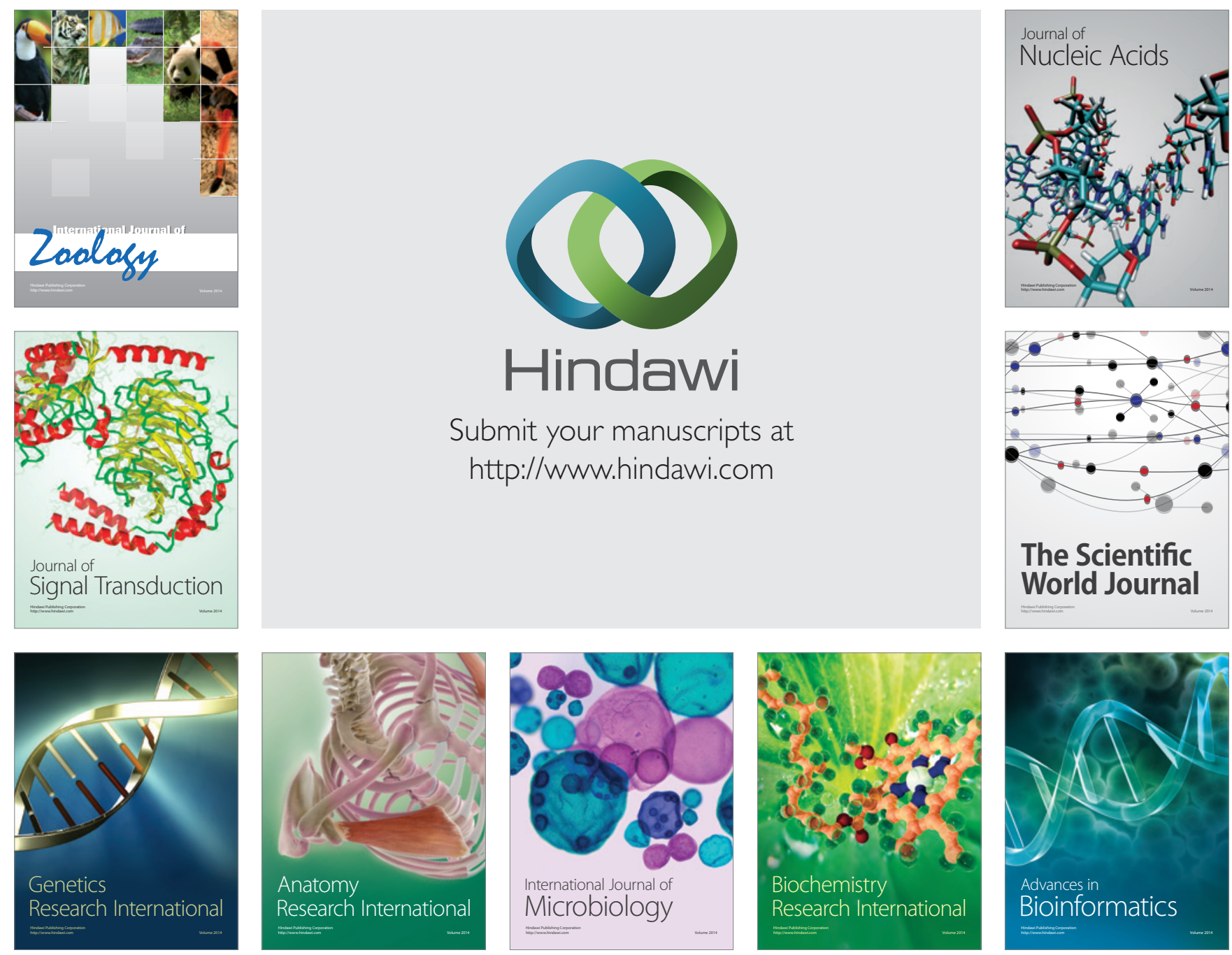

The Scientific World Journal
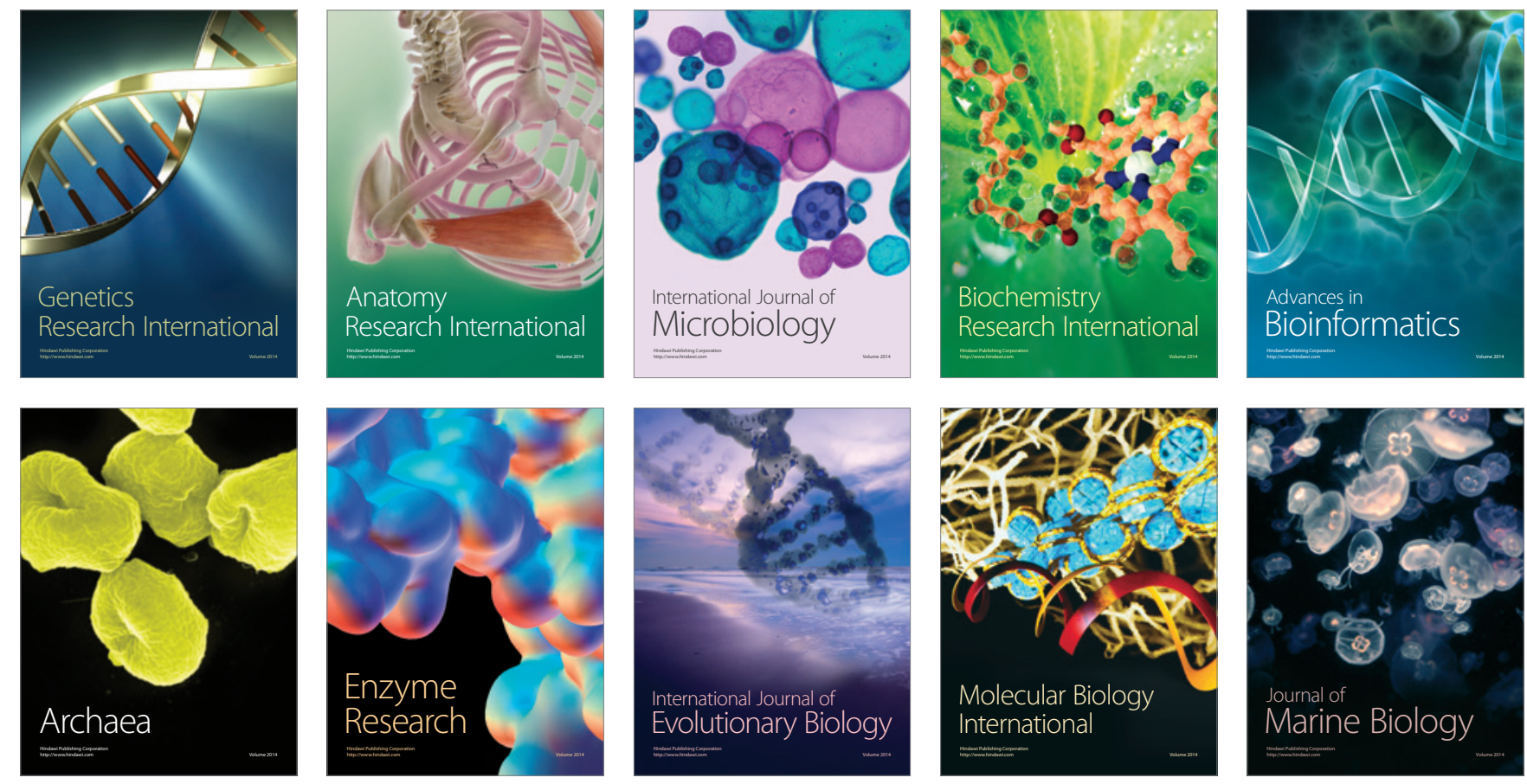